\title{
FAKTOR-FAKTOR YANG MEMPENGARUHI KEBIJAKAN DIVIDEN PADA PERUSAHAAN NON KEUANGAN DI INDONESIA
}

\author{
MEIRYANANDA PERMANASARI
}

\author{
STIE Trisakti \\ meiryananda@stietrisakti.ac.id
}

\begin{abstract}
The purpose of this research is to examine the variables that influence dividend policy on non-financial companies in Indonesian and to get the empirical evidence whether variables being respectively examined were financial performance, firm size, financial leverage, board independence, free cash flow, firm growth, liquidity, earnings per share, and net profit margin. Dividend payout ratio was used as proxies of dividend policy. The population of this research is 413 nonfinancial companies. Sampling techniques that used in this research is purposive sampling. There are 73 non-financial companies listed from 2010 to 2012 which met the criterion used as sample. Analysis method of this research is multiple regressions. The result of this research conclude that financial performance, firm size, free cash flow, firm growth, and earnings per share have influence toward dividend policy. Other variable such as financial leverage, board independence, liquidity, and net profit margin don't have influence to dividend policy.
\end{abstract}

Keywords: Dividend Policy, Financial Performance, Firm Size, Financial Leverage, Board Independence, and Free Cash Flow.

\begin{abstract}
Abstrak: Tujuan penelitian adalah untuk menguji variabel-variabel yang mempengaruhi kebijakan dividen perusahaan non-keuangan di Indonesia dan untuk mendapatkan bukti empiris apakah variabel yang diteliti masing-masing adalah kinerja keuangan, ukuran perusahaan, leverage keuangan, independensi dewan, arus kas bebas, perusahaan Pertumbuhan, likuiditas, laba bersih per saham, dan marjin laba bersih. Dividen payout ratio digunakan sebagai proxy kebijakan dividen. Populasi penelitian ini adalah 413 perusahaan non keuangan. Teknik pengambilan sampel yang digunakan dalam penelitian adalah purposive sampling. Ada 73 perusahaan non-keuangan yang terdaftar dari 2010 hingga 2012 yang memenuhi kriteria yang digunakan sebagai sampel. Metode analisis yang digunakan dalam penelitian ini adalah regresi berganda. Hasil penelitian menunjukkan bahwa kinerja keuangan, ukuran perusahaan, arus kas bebas, pertumbuhan perusahaan, dan laba per saham berpengaruh terhadap kebijakan dividen. Variabel lain seperti financial leverage, board independence, likuiditas, dan net profit margin tidak berpengaruh terhadap kebijakan dividen.
\end{abstract}


Kata kunci: Dividend Policy, Financial Performance, Firm Size, Financial Leverage, Board Independence, and Free Cash Flow.

\section{PENDAHULUAN}

Pada saat ini, isu yang sedang hangat diperbincangkan adalah mengenai pasar bebas ASEAN yang akan terjadi pada tahun 2015. Pasar bebas ASEAN adalah suatu kondisi di mana setiap perusahaan yang terdaftar dalam ASEAN dapat lebih mudah memasuki pasar yang termasuk dalam anggota ASEAN. Pasar bebas ASEAN tersebut menimbulkan kompetisi yang semakin sengit diantara perusahaan, baik dalam negeri maupun luar negeri. Persaingan tersebut dapat mengakibatkan setiap perusahaan akan berjuang untuk mengembangkan perusahaan.

Dalam mengembangkan dan mempertahankan perusahaan, tidak hanya butuh manajemen yang baik namun juga membutuhkan suntikan dana yang dapat digunakan untuk melakukan ekspansi yang dapat lebih mengembangkan perusahaan. Suntikan dana yang dapat diperoleh perusahaan dapat bersumber dari investor. Dalam berinvestasi saham, pemegang saham sebagai investor mengharapkan imbal hasil dari perusahaan dalam bentuk dividen atau capital gain yang dapat dipilih oleh investor sesuai dengan tujuan dan kebutuhannya (Lucyanda dan Lilyana, 2012). Motivasi peneliti melakukan penelitian ini adalah terdapat perbedaan dengan simpulan penelitian terdahulu. Masalah pada penelitian ini adalah apakah kinerja keuangan, ukuran perusahaan, financial leverage, board independence, aliran kas bebas, pertumbuhan perusahaan, likuiditas, laba per lembar saham dan net profit margin mempengaruhi terhadap kebijakan dividen. Tujuan dari penelitian ini adalah untuk mendapat bukti empiris bahwa kinerja keuangan, ukuran perusahaan, financial leverage, board independence, aliran kas bebas, pertumbuhan perusahaan, likuiditas, laba per lembar saham dan net profit margin berpengaruh terhadap kebijakan dividen.
Penelitian ini disusun dengan sistematika penulisan adalah pertama, pendahuluan menjelaskan latar belakang penelitian, masalah penelitian, tujuan penelitian, dan sistematika penelitian. Kedua, rerangka teoritis, penelitian terdahulu, model penelitian, dan pengembangan hipotesis. Ketiga, bentuk penelitian, obyek penelitian, definisi operasional variabel dan pengukurannya, teknik pengumpulan data dan metode analisis data yang digunakan dalam penelitian. Keempat, hasil penelitian yang berisi hasil pengujian hipotesis dan interpretasi pengujian hipotesis. Terakhir, penutup yang berisi kesimpulan, keterbasan dan rekomendasi untuk penelitian selanjutnya.

\section{Agency Theory}

Menurut Rachmad dan Muid (2013), agency theory merupakan teori yang menjelaskan konflik yang terjadi antara pemegang saham dan manajer di mana dalam melaksanakan manajemen perusahaan, manajer tidak boleh bertindak untuk kepentingan individunya daripada kepentingan pemegang saham maka perusahaan akan dirugikan.

\section{Bird-In-The-Hand Theory}

Bird-in-the-hand theory adalah teori yang menjelaskan bahwa investor melihat dividen yang diterima sekarang mempunyai risiko yang lebih kecil dibanding dengan dividen dimasa mendatang atau capital gain (Gitman dan Zutter, 2012).

\section{Residual Theory}

Menurut Gitman dan Zutter (2012), residual theory adalah sebuah teori yang menunjukkan bahwa dividen yang dibayarkan oleh perusahaan harus dipandang sebagai sisa. 


\section{Signaling Theory}

Signaling theory adalah teori di mana investor melihat perubahan dividen sebagai sinyal dari peramalan laba oleh manajemen perusahaan (Weston et al., 1996). Menurut Ross et al. (2009), signaling theory adalah reaksi pa-sar pada perubahan dalam pembagian dividen perusahaan.

\section{Kinerja Keuangan dan Kebijakan Dividen}

Kinerja keuangan adalah usaha yang dilakukan oleh perusahaan yang digunakan untuk mengukur keberhasilan perusahaan dalam menghasilkan laba. Kinerja keuangan mencerminkan kondisi keuangan suatu perusahaan dalam menghasilkan laba. Kinerja keuangan tersebut memberikan sinyal tersendiri bagi pemegang saham, hal itu sesuai dengan signaling theory. Hal tersebut sesuai dengan penelitian yang dilakukan oleh Ranti (2013), kinerja keuangan berpengaruh terhadap kebijakan dividen.

\section{$\mathrm{H}_{1} \quad$ Kinerja keuangan berpengaruh terhadap kebijakan dividen.}

\section{Ukuran Perusahaan dan Kebijakan Dividen}

Menurut Hardiatmo dan Daljono (2013), ukuran perusahaan menjelaskan keadaan suatu perusahaan yang dapat membedakan akses perusahaan ke dalam pasar modal, di mana perusahaan yang memiliki ukuran perusahaan besar lebih mudah masuk ke pasar modal dibandingkan dengan perusahaan yang ukuran perusahaannya kecil. Oleh karena itu, ukuran perusahaan dapat berpengaruh terhadap kebijakan dividen suatu perusahaan. Hal tersebut sesuai dengan penelitian yang dilakukan oleh Ranti (2013), ukuran perusahaan berpengaruh terhadap kebijakan dividen.

$\mathrm{H}_{2} \quad$ Ukuran perusahaan berpengaruh terhadap kebijakan dividen.

\section{Financial Leverage dan Kebijakan Dividen}

Financial leverage adalah rasio yang mengukur seberapa jauh perusahaan menggu- nakan hutang (Husnan, 1992). Hal tersebut sesuai dengan residual theory di mana perusahaan membagikan dividen setelah menggunakan dananya untuk kepentingan perusahaan terlebih dahulu sebelum membagikan dividen. Penjelasan tersebut sesuai dengan penelitian Ranti (2013), Rachmad dan Muid (2013), dan Sumiadji (2011), financial leverage berpengaruh terhadap dividend payout ratio.

$\mathrm{H}_{3} \quad$ Financial leverage berpengaruh terhadap kebijakan dividen.

\section{Board Independence dan Kebijakan Dividen}

Menurut Alijoyo dan Zaini (2004), board independence terdiri dari dua boards yaitu supervisory board (komisaris) dan executive board (direksi). Board independence membuat pemegang saham menjadi optimis bahwa pihak manajemen tidak terlalu mengalokasikan dana yang dimiliki perusahaan untuk mengembangkan perusahaan dan memungkinkan dananya digunakan untuk membagikan dividen. Hal tersebut sesuai dengan kesimpulan Ranti (2013) yang menyatakan bahwa board independence berpengaruh terhadap kebijakan dividen.

$\mathrm{Ha}_{4}$ Board Independence berpengaruh terhadap kebijakan dividen.

\section{Aliran Kas Bebas dan Kebijakan Dividen}

Menurut Hatta (2002), aliran kas bebas adalah kas yang menganggur, yaitu sisa kas setelah digunakan untuk berbagai keperluan proyek yang telah direncanakan perusahaan, seperti melunasi hutang, membayar dividen, melakukan investasi, dan lainnya. Dengan adanya sisa kas bebas dapat menimbulkan keyakinan di mana pemegang saham yakin bahwa dengan adanya sisa kas tersebut dapat digunakan untuk membagikan dividen. Hal tersebut sesuai dengan kesimpulan Lucyanda dan Lilyana (2012) yang menyatakan bahwa free cash flow berpengaruh terhadap dividend payout ratio.

$\mathrm{H}_{5} \quad$ Aliran kas bebas berpengaruh terhadap kebijakan dividen. 


\section{Pertumbuhan Perusahaan dan Kebijakan Dividen}

Pertumbuhan perusahaan akan membuat aktivitas operasi tinggi yang dapat menyebabkan pendanaan perusahaan lebih difokuskan untuk mengembangkan pertumbuhan atau dana lebih difokuskan untuk kegiatan operasi (Hardiatmo dan Daljono, 2013). Hal yang terjadi tersebut sangat mengecewakan pemegang saham sesuai dengan bird-in-the-hand theory, di mana pemegang saham lebih menyukai dividen saat ini dibanding capital gain yang akan diterima dimasa akan datang setelah perusahaan mengalami pertumbuhan. Hal tersebut sesuai dengan penelitian yang dilakukan Hikmah dan Astuti (2013) dan Git et al. (2010) yang menyatakan bahwa pertumbuhan perusahaan berpengaruh terhadap kebijakan dividen.

$\mathrm{H}_{6} \quad$ Pertumbuhan perusahaan berpengaruh terhadap kebijakan dividen.

\section{Likuiditas dan Kebijakan Dividen}

Likuiditas adalah kemampuan suatu perusahaan memenuhi kewajiban keuangan jangka pendek (Husnan, 1992). Semakin likuid suatu perusahaan dapat memberikan informasi kepada pemegang saham, bahwa perusahaan mungkin dapat membagikan dividen yang lebih besar. Hal tersebut sesuai dengan penelitian yang dilakukan oleh Sumiadji (2011), di mana current ratio yang merupakan alat ukur dari likuiditas berpengaruh terhadap kebijakan dividen.

$\mathrm{H}_{7} \quad$ Likuiditas berpengaruh terhadap kebijakan dividen.

\section{Laba per Lembar Saham dan Kebijakan Dividen}

Menurut Weygandt et al. (2011), laba per lembar saham adalah ukuran dari laba bersih yang diperoleh pada setiap saham biasa. Semakin tingginya laba per lembar saham memperlihatkan bahwa semakin banyak dana yang dapat digunakan perusahaan untuk membagikan dividen. Hal tersebut sesuai dengan penelitian Deitiana (2009) yang menyatakan bahwa earnings per share berpengaruh terhadap pembayaran dividen kas.

$\mathrm{H}_{8} \quad$ Laba per lembar saham berpengaruh terhadap kebijakan dividen.

\section{Net Profit Margin}

Menurut Weygandt et al. (2011), net profit margin adalah ukuran setiap nilai uang dari penjualan yang menghasilkan laba bersih. Apabila kondisi perusahaan baik akan meningkatkan keyakinan bahwa perusahaan akan membagikan dividen kepada pemegang saham sedangkan kalau tidak baik akan terjadi sebaliknya. Hal tersebut sesuai dengan signaling theory yang menyatakan bahwa kondisi rasio yang dihitung dari net profit margin adalah suatu informasi bagi pemegang saham dalam melihat penetapan kebijakan dividen. Hal tersebut sesuai dengan penelitian Sadalia dan Saragih (2008) dan Rahmawati et al. (2014).

$\mathrm{H}_{9} \quad$ Laba per lembar saham berpengaruh terhadap kebijakan dividen.

Berikut adalah model penelitian : 


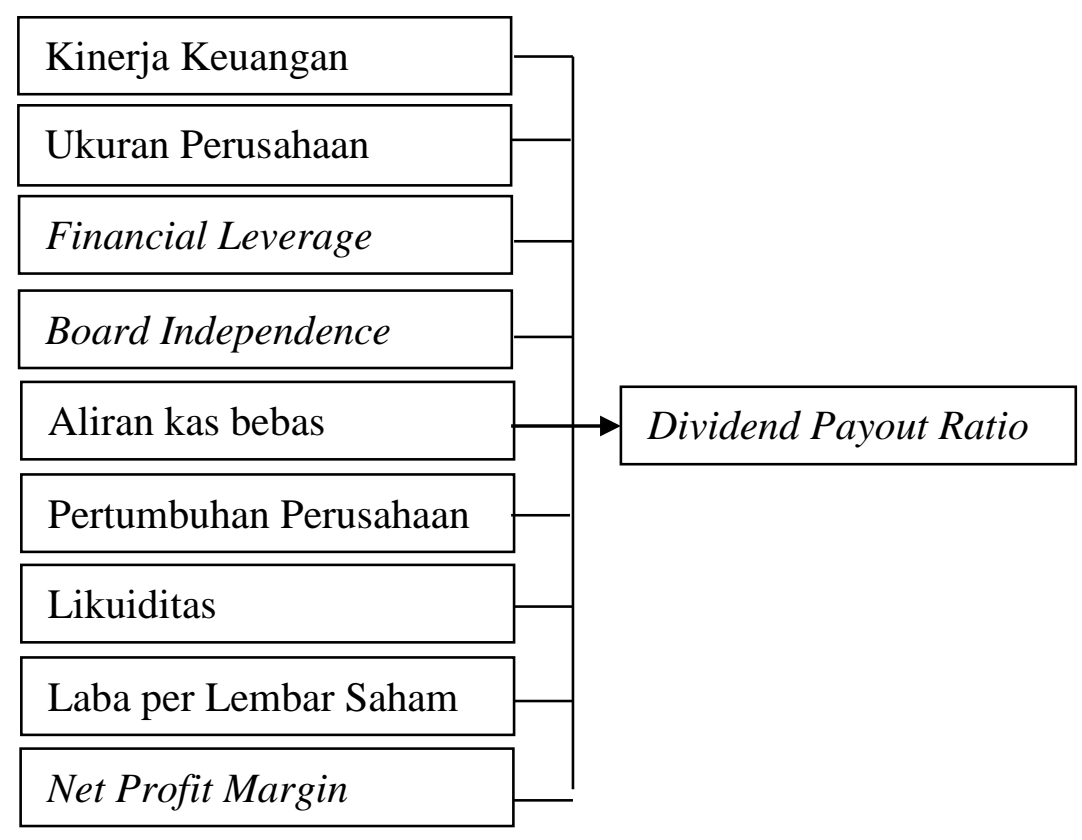

\section{Gambar 1 Model Penelitian}

\section{METODE PENELITIAN}

Metode yang digunakan dalam pemilihan sampel akan dilakukan dengan metode purposive sampling yaitu sampel dalam penelitian harus memenuhi kriteria yang telah ditetapkan (Sekaran dan Bougie 2013). Berikut adalah hasil pemilihan sample:

Tabel 1 Prosedur Pemilihan Sampel

\begin{tabular}{lcc}
\hline \multicolumn{1}{c}{ Keterangan } & Jumlah & Total Data \\
\hline $\begin{array}{l}\text { Perusahaan non keuangan yang konsisten terdaftar di Bursa Efek } \\
\text { Indonesia pada periode 2009-2013 }\end{array}$ & 304 & 912 \\
$\begin{array}{l}\text { Perusahaan non keuangan yang tidak menerbitkan laporan keuangan } \\
\text { dalam mata uang rupiah pada periode 2009-2013 }\end{array}$ & $(25)$ & $(75)$ \\
$\begin{array}{l}\text { Perusahaan non keuangan yang tidak memiliki laporan keuangan yang } \\
\text { berakhir pada tanggal 31 Desember pada periode 2009-2013 }\end{array}$ & $(11)$ & $(33)$ \\
$\begin{array}{l}\text { Perusahaan non keuangan yang tidak memiliki laba setelah pajak pada } \\
\text { periode 2010-2012 }\end{array}$ & $(75)$ & $(225)$ \\
$\begin{array}{l}\text { Perusahaan non keuangan yang tidak konsisten membagikan dividen } \\
\text { pada periode 2010-2012 }\end{array}$ & $(96)$ & $(288)$ \\
$\begin{array}{l}\text { Perusahaan non keuangan yang tidak memiliki komisaris independen } \\
\text { pada periode 2010-2012 } \\
\text { Jumlah data perusahaan sebelum outlier } \\
\begin{array}{l}\text { Jumlah data perusahaan yang dihilangkan } \\
\text { Jumlah data perusahaan setelah outlier }\end{array}\end{array}$ & $(24)$ & $(72)$ \\
\hline
\end{tabular}


Kebijakan dividen adalah keputusan yang dibuat oleh pihak perusahaan pada saat Rapat Umum Pemegang Saham untuk membagikan dividen kepada pihak pemegang saham. Kebijakan dividen diukur menggunakan dividend payout ratio (Ranti, 2013) dengan skala rasio sebagai berikut :

$$
\mathrm{DPR}=\frac{\mathrm{DPS}}{\mathrm{EPS}}
$$

Kinerja keuangan adalah usaha yang dilakukan oleh perusahaan yang digunakan untuk mengukur keberhasilan perusahaan dalam menghasilkan laba. Kinerja keuangan dalam penelitian ini dapat diproksikan dalam return on equity (Ranti, 2013) dengan skala rasio sebagai berikut:

$$
R O E=\frac{\text { Net Profit After Tax }}{\text { Shareholders Equity }}
$$

Ukuran perusahaan merupakan alat untuk mengukur besar atau kecil dari suatu perusahaan. Berdasarkan Ranti (2013) diukur dengan skala rasio dan cara sebagai berikut :

FZ = natural logarithm of the book value of the firms Total Asset

Financial leverage adalah rasio yang mengukur seberapa jauh perusahaan menggu-nakan hutang (Husnan, 1992). Menurut Ranti (2013), variabel debt to equity ratio dapat dihitung dengan skala rasio dan menggunakan rumus sebagai berikut :

$$
\text { DER }=\frac{\text { Total Debt }}{\text { Total Equity }}
$$

Menurut Alijoyo dan Zaini (2004), board independence adalah jajaran komisaris yang tidak memiliki hubungan dengan pihak manapun yang diukur dengan skala rasio dengan rumus sebagai berikut :

$$
\mathrm{BI}=\frac{\text { Total Komisaris Independen }}{\text { Total Komisaris }}
$$

Menurut Arilaha (2009), aliran kas bebas berasal dari aliran kas operasi perusahaan dikurangi dengan pengeluaran modal dan modal kerja bersih perusahaan. Dari pengertian tersebut maka aliran kas bebas diukur dengan skala rasio dan memiliki rumus sebagai berikut :

\section{FCF = Aliran Kas Operasi-Pengeluaran Modal- Modal Kerja Bersih}

Pertumbuhan perusahaan adalah kondisi di mana suatu perusahaan mengalami peningkatan dari periode sebelumnya. Menurut Hikmah dan Astuti (2013), pertumbuhan perusahaan dapat dihitung dengan menggunakan skala rasio dan rumus sebagai berikut :

$$
\text { GROWTH }=\frac{{\text { Sales }(t)-\text { Sales }_{(t-1)}}_{\text {Sales }(t-1)}}{\text { Gat }}
$$

Menurut Husnan (1992), likuiditas adalah kondisi di mana perusahaan dapat memenuhi kewajiban jangka pendeknya dapat diukur dengan skala rasio dan rumus sebagai berikut :

$$
\mathrm{CR}=\frac{\text { Current Asset }}{\text { Current Liabilities }}
$$

Laba per lembar saham keuntungan bersih setalah pajak yang diterima oleh perusa-haan per lembar saham biasa yang beredar di masyarakat. Menurut Weygandt et al. (2011) laba per lembar saham dapat dihitung dengan skala rasio dan rumus sebagai berikut :

$$
\text { EPS }=\frac{\text { Net Income }- \text { Preference Dividends }}{\text { Weighted-average ordinary shares outstanding }}
$$

Net profit margin tersebut merujuk pada perbandingan antara net income dengan net sales. Menurut Weygandt et al. (2011), net profit margin dapat dihitung dengan skala rasio dan menggunakan rumus sebagai berikut :

$$
\mathrm{NPM}=\frac{\text { Net Income }}{\text { Net Sales }}
$$


Pengujian hipotesis dalam penelitian ini menggunakan uji regresi berganda (multiple regression). Pengujian ini bertujuan untuk menguji apakah variabel independen berpengaruh terhadap variabel dependen. Model penelitian dengan persamaan regresi dalam penelitian ini dirumuskan sebagai berikut :

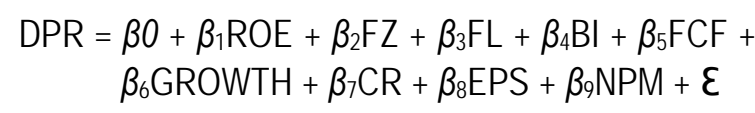

Keterangan:

$\begin{array}{ll}\mathrm{DPR} & =\text { Kebijakan Dividen } \\ \beta 1-\beta 7 & =\text { Koefisien Regresi } \\ \beta 0 & =\text { Konstanta } \\ \mathrm{ROE} & =\text { Kinerja Keuangan }\end{array}$

$\begin{array}{ll}\text { FZ } & =\text { Ukuran Perusahaan } \\ \text { FL } & =\text { Finacial Leverage } \\ \text { BI } & =\text { Board Independence } \\ \text { FCF } & =\text { Aliran Kas Bebas } \\ \text { GROWTH } & =\text { Pertumbuhan Perusahaan } \\ \text { CR } & =\text { Likuiditas } \\ \text { EPS } & =\text { Laba per Lembar Saham } \\ \text { NPM } & =\text { Net Profit Margin } \\ \varepsilon & =\text { error }\end{array}$

HASIL PENELITIAN

Statistik deskriptif untuk mengetahui gambaran data dapat dilihat pada tabel 3 berikut:

Tabel 3 Hasil Pengolahan Statistik Deskriptif

\begin{tabular}{lcrrrr}
\hline Variabel & $N$ & \multicolumn{1}{c}{ Minimum } & \multicolumn{1}{c}{ Maximum } & \multicolumn{1}{c}{ Mean } & Std. Deviation \\
\hline DPR & 213 & 0,0134 & 1,0301 & 0,384355 & 0,2023692 \\
ROE & 213 & 0,0118 & 1,2194 & 0,219439 & 0,1583504 \\
FZ & 213 & 25,6606 & 32,8365 & 28,90728 & 1,5046909 \\
FL & 213 & 0,073 & 5,6661 & 1,005397 & 0,8871565 \\
BI & 213 & 0,25 & 1 & 0,410086 & 0,1166808 \\
FCF & 213 & $-2.27060 \mathrm{E} 13$ & $2.7341786 \mathrm{E} 13$ & $-1.05644 \mathrm{E} 12$ & $4.515130 \mathrm{E} 12$ \\
GROWTH & 213 & $-0,2644$ & 0,646 & 0,15742 & 0,1236403 \\
CR & 213 & 0,3624 & 11,7428 & 2,518727 & 2,0840175 \\
EPS & 213 & 3 & 10320 & 532,6442 & 1135,2324 \\
NPM & 213 & 0,0047 & 0,9337 & 0,125882 & 0,1149365 \\
\hline
\end{tabular}
berikut ini:

Hasil uji t dapat dilihat pada tabel 4

\section{Tabel 4 Hasil Uji t}

\begin{tabular}{lcrl}
\hline Variabel & B & \multicolumn{1}{c}{ Sig. } & Kesimpulan \\
\hline (Constant) & $-0,216$ & 0,35 & \\
ROE & 0,596 & 0,000 & Ha diterima \\
FZ & 0,015 & 0,049 & Ha diterima
\end{tabular}

\begin{tabular}{lcrl} 
FL & $-0,027$ & 0,089 & Ha tidak diterima \\
BI & 0,158 & 0,111 & Ha tidak diterima \\
FCF & $7,52 E-15$ & 0,005 & Ha diterima \\
GROWTH & $-0,26$ & 0,005 & Ha diterima \\
CR & 0,001 & 0,831 & Ha tidak diterima \\
EPS & $2,69 E-05$ & 0,01 & Ha diterima \\
NPM & 0,127 & 0,265 & Ha tidak diterima \\
\hline
\end{tabular}


Berdasarkan hasil uji t dalam tabel 4 . diketahui bahwa kinerja keuangan (ROE) mempunyai pengaruh terhadap kebijakan dividen. Dalam model regresi terlihat bahwa kinerja keuangan perusahaan memiliki nilai koefisien 0,596 yang memperlihatkan bahwa kinerja keuangan memiliki pengaruh positif terhadap kebijakan dividen. Hal memperlihatkan bahwa kinerja keuangan menyebabkan laba yang tinggi dalam perusahaan dan tingginya laba akan menambah kemungkinan pembayaran dividen yang dilakukan oleh perusahaan (Ranti, 2013). Variabel ukuran perusahaan (FZ) dalam penelitian ini memiliki nilai signifikasi 0,049 lebih kecil dari $\alpha=0,05$ yang memperlihatkan ukuran perusahaan mempunyai pengaruh terhadap kebijakan dividen. Dalam model regresi terlihat bahwa ukuran perusahaan memiliki nilai koefisien 0,015 yang memperlihatkan bahwa kinerja keuangan memiliki pengaruh positif terhadap kebijakan dividen. Hal tersebut memperlihatkan bahwa dengan ukuran perusahaan yang besar, maka perusahaan tersebut akan lebih mudah menghimpun dana dari pemegang saham dan menyebabkan pendanaan dari internal akan berkurang dan perusahaan tidak memakai sistem bagi hasil kepada pemilik modal internal namun pembagian dividen kepada pemegang saham (Ranti, 2013).

Variabel financial leverage (FL) tingkat signifikansi sebesar 0,089 lebih besar dari $a=$ 0,05 yang menunjukkan bahwa financial leverage tidak mempunyai pengaruh terhadap kebijakan dividen. Hal tersebut terjadi karena berdasarkan residual theory kebijakan dividen ditetapkan berdasarkan dana sisa yang dimiliki perusahaan (Gitman dan Zutter, 2012) bukan dipengaruhi oleh kebijakan perusahaan menggunakan utang dalam menjalankan usahanya. Variabel board independence (BI) memiliki tingkat signifikansi sebesar 0,111 lebih besar dari $a=0,05$ yang menunjukkan bahwa board independence tidak mempunyai pengaruh terhadap kebijakan dividen. Hal tersebut terjadi karena peran komisaris yang lemah dalam melaksanakan fungisnya dalam menetapkan kebijakan dividen (Alijoyo dan Zaini, 2004).

Variabel aliran kas bebas (FCF) memiliki tingkat signifikansi sebesar 0,005 lebih kecil dari $a=0,05$ yang menunjukkan bahwa aliran kas bebas mempunyai pengaruh terhadap kebijakan dividen. Dalam model regresi aliran kas bebas (FCF) memiliki nilai koefisien 0,000000000000007521 yang memperlihatkan bahwa aliran kas bebas memiliki pengaruh positif terhadap kebijakan dividen. Kondisi tersebut sesuai dengan residual theory yang menyatakan bahwa semakin banyaknya sisa dana maka akan meningkatkan kebijakan dividen dalam pembagian dividen yang dilakukan oleh perusahaan (Gitman dan Zutter, 2012). Variabel pertumbuhan perusahaan (GROWTH) memiliki tingkat signifikansi sebesar 0,005 lebih kecil dari $a=0,05$ yang menunjukkan bahwa pertumbuhan perusahaan mempunyai pengaruh terhadap kebijakan dividen. Dalam model regresi pertumbuhan perusahaan memiliki nilai koefisien $-0,26$ yang memperlihatkan bahwa pertumbuhan perusahaan memiliki pengaruh negatif terhadap kebijakan dividen. Pengaruh negatif tersebut dapat terjadi karena pertumbuhan perusahaan akan membuat aktivitas operasi tinggi yang dapat menyebabkan pendanaan perusahaan lebih difokuskan untuk mengembangkan pertumbuhan atau dana lebih difokuskan untuk kegiatan operasi dibanding untuk pembagian dividen (Hardiatmo dan Daljono, 2013).

Variabel likuiditas (CR) memiliki tingkat signifikansi sebesar 0,831 lebih besar dari $a=$ 0,05 yang menunjukkan bahwa likuiditas tidak mempunyai pengaruh terhadap kebijakan dividen. Likuiditas tidak berpengaruh terhadap kebijakan dividen karena berdasarkan residual theory menyatakan bahwa sebuah perusahaan membayar dividen hanya setelah memenuhi kebutuhan investasinya sementara mempertahankan rasio utang terhadap ekuitas yang diinginkan sehingga tidak berhubungan dengan kemampuan perusahaan dalam melunasi kewajiban jangka pendek (Ross et al., 2009). Variabel laba per lembar saham (EPS) memiliki 
tingkat signifikansi sebesar 0,01 lebih kecil dari $=0,05$ yang menunjukkan bahwa laba per lembar saham mempunyai pengaruh terhadap kebijakan dividen. Dalam model regresi laba per lembar saham memiliki nilai koefisien 0,0000269 yang memperlihatkan bahwa laba per lembar saham memiliki pengaruh positif terhadap kebijakan dividen. Kondisi tersebut terjadi karena dividen akan dibagikan apabila perusahaan memperoleh keuntungan bersih yang diperoleh perusahaan sehingga apabila keuntungan bersih yang dimiliki oleh perusahaan semakin besar maka akan meningkatkan kemugkin pembagian dividen (Sumiadji, 2011). Variabel net profit margin (NPM) memiliki tingkat signifikansi sebesar 0,265 lebih besar dari $a=$ 0,05 yang menunjukkan bahwa net profit margin tidak mem-punyai pengaruh terhadap kebijakan dividen. Hal tersebut terjadi karena laba tersebut dapat dialokasikan bukan hanya untuk pembayaran dividen melainkan untuk laba ditahan (Deitiana, 2013).

\section{PENUTUP}

Berdasarkan hasil penelitian dapat ditarik simpulan bahwa kinerja keuangan, ukuran perusahaan, aliran kas bebas, pertumbuhan perusahaan, dan laba per lembar saham berpengaruh terhadap kebijakan dividen, sementara itu financial leverage, board independence, likuiditas, dan net profit margin tidak berpengaruh terhadap kebijakan dividen.

Penelitian ini memiliki beberapa keterbatasan, yaitu penelitian ini hanya menggunakan sampel perusahaan non keuangan yang terdaftar di Bursa Efek Indonesia, periode penelitian yang digunakan dalam penelitian ini hanya mencakup tiga tahun, yaitu dari tahun 2010-2012, penelitian ini hanya menggunakan sembilan variabel independen, penelitian ini terjadi masalah regresi heteroskedastisitas, dan penelitian ini terdapat variabel board independence yang diukur dengan rasio non-executive director dibagi total directors, namun di perusahaan Indonesia sangat langka yang mempunyai struktur organisasi non-executive director. Untuk mengatasi keterbatasan itu maka rekomendasi yang diberikan, yaitu penelitian berikutnya diharapkan dapat menambah jumlah sampel penelitian dengan mengikutsertakan perusahaan dari sektor industri lain, penelitian berikutnya diharapkan dapat menambah jumlah tahun penelitian agar memperoleh sampel lebih banyak dan data yang digunakan, penelitian selanjutnya dapat menambahkan variabel lain yang dapat mempengaruhi kebijakan dividen, penelitian selanjutnya diharapakan tidak terjadi masalah regresi heteroskedastisitas dan penelitian berikutnya diharapkan mempunyai sumber penelitian yang menggunakan variabel board independence yang diukur dengan rasio yang sesuai dengan kondisi di Indonesia.

\section{REFERENSI:}

Adil, Muhammad Ch, Nousheen Zafar, dan Noman Yassen. 2011. Empirical Analysis of Determinants of Dividend Payout: Profitability and Liquidity. Interdisciplinary Journal of Contemporary Research in Business. Vol 3, No. 1.

Afza, Talat. 2010. Ownership Structure and Cash Flow As Determinants of Corporate Dividend Policy in Pakistan. International Business Research, Vol. 3, No. 3.

Alijoyo, Antonius dan Subarto Zaini. 2004. Komisaris Independen Penggerak Praktik GCG di Perusahaan. Jakarta: PT INDEKS Kelompok Gramedia.

Amah, Nik. 2012. Faktor-Faktor Yang Mempengaruhi Dividend Policy Perusahaan Go Public di Indonesia. Jurnal Akuntansi dan Pendidikan, Vol 1, No. 1.

Anderson, David R., Dennis J. Sweeny, and Thomas A. William. 2014. Statistics for Business and Economics 12 th edition. Canada: Cengage Learning. 
Arilaha, Muhammad Asril. 2009. Pengaruh Free Cash Flow, Profitabilitas, Likuiditas, dan Leverage Terhadap Kebijakan Dividen. Jurnal Keuangan dan Perbankan, Vol. 13, No. 1: 78-87.

Deitiana, Tita. 2009. Faktor-Faktor Yang Mempengaruhi Kebijakan Pembayaran Dividen Kas. Jurnal Bisnis dan Akuntansi, Vol. 11, No. 1: 57-64.

Deitiana, Tita. 2013. Pengaruh Current Ratio, Return on Equity dan Total Asset Turn Over Terhadap Devidend Payout Ratio dan Implikasi Pada Harga Saham Perusahaan LQ 45. Jurnal Bisnis dan Akuntansi, Vol. 15, No. 1: 82-88.

Departemen Pendidikan Nasional. 2008. Kamus Besar Bahasa Indonesia. Jakarta: Pusat Bahasa.

Dewan Standar Akuntansi Keuangan. 2012. Pernyataan Standar Akuntansi Keuangan No. 23. Jakarta: Ikatan Akuntan Indonesia.

Gill, Amarjit, Nahum Biger, and Rajendra Tibrewala. 2010. Determinants of Dividend Payout Ratio: Evidence from United States. The Open Business Journal, 3: 8-14.

Gitman, Lawrence J. and Chad J. Zutter. 2012. Principles of Managerial Finance. Global Edition. Thirteenth Edition. Boston: Pearson Education Limited.

Ghozali, Imam. 2013. Aplikasi Analisis Multivariate Dengan Program IBM SPSS 21 Update PLS Regresi. Edisi 7. Semarang: Badan Penerbit Universitas Diponegoro.

Hair, Joseph F., William C. Black, Barry J. Babin, Rolph E. Anderson, and Ronald L. Tatham. 2006. Multivariate Data Analysis. International Edition. Sixth Edition. United States of America: Pearson Prentice Hall.

Hair, Joseph F., William C. Black, Barry J. Babin, Rolph E. Anderson, and Ronald L. Tatham. 2010. Multivariate Data Analysis. International Edition. Seventh Edition. United States of America: Pearson Prentice Hall.

Handiwidjaja, Rini dan Lely Fera Triani. 2009. Pengaruh Profitabilitas Terhadap Dividend Payout Ratio Pada Perusahaan Manufaktur di Indonesia. Jurnal Organisasi dan Manajemen, Vol 5, No. 2: 49-54.

Hardiatmo, Budi dan Daljono. 2013. Analisis Faktor - Faktor Yang Mempengaruhi Kebijakan Dividen (Studi Empiris Perusahaan Manufaktur yang listing di Bursa Efek Indonesia Periode 2008 - 2010). Diponegoro Journal of Accounting, Vol. 12, No. 1: 1-13.

Hatta, Atika Jauhari. 2002. Faktor-Faktor Yang Mempengaruhi Kebijakan Deviden: Investigasi Pengaruh Teori Stakeholder. JAAl, Vol. 6, No. 2.

Hikmah, Khoirul dan Ririn Astuti. 2013. Growth of Sales, Investment, Liquidity, Profitability, dan Size of Firm Terhadap Kebijakan Dividende Payout Ratio Pada Perusahaan Manufaktur Yang Terdaftar Di Bursa Efek Indonesia. Jurnal Manajemen dan Akuntansi, Vol. 2, No. 1.

Husnan, Suad. 1992. Manajemen Keuangan Teori dan Penerapan (Keputusan Jangka Pendek). Yogyakarta: BPFE-Yogyakarta.

Lucyanda, Jurica dan Lilyana. 2012. Pengaruh Free Cash Flow dan Struktur Kepemilikan Terhadap Dividend Payout Ratio. Jurnal Dinamika Akuntansi, Vol 4, No. 2: 129-138.

Pasaribu, Rowland Bismark Fernando, Dionysia Kowanda, dan Kholid Nawawi. Determinan Dividend Payout Ratio Pada Emiten LQ-45 di Bursa Efek Indonesia. Jurnal Ekonomi dan Bisnis, Vol. 8, No. 1.

Pribadi, Anggit Satria, dan R. Djoko Sampurno. 2012. Analisis Pengaruh Cash Position, Firm Size, Growth Opportunity, Ownership, dan Return on Asset Terhadap Dividend Payout Ratio. Dipenogoro Journal of Management, Vol. 1, No. 1: 212-211.

Rachmad, Anggie Noor dan Dul Muid. 2013. Pengaruh Struktur Kepemilikan, Leverage, dan Return on Assets (ROA) Terhadap Kebijakan Dividen (Studi Empiris pada Perusahaan Nonkeuangan yang Terdaftar di Bursa Efek Indonesia). Diponegoro Journal of Accounting, Vol. 2, No. 3: 1-11.

Rahayuningtyas, Septi, Suhadak, dan Siti Ragil Handayani. 2014. Pengaruh Rasio-Rasio Keuangan Terhadap Dividend Payout Ratio (DPR) (Studi Pada Perusahaan Yang Listing di BEI Tahun 2009-2011). Jurnal Administrasi Bisnis, Vol. 7, No. 2.

Rahmawati, Nining Dwi, Ivonne S. Saerang, dan Paulina Van Rate. 2014. Kinerja Keuangan Pengaruhnya Terhadap Kebijakan Dividen Pada Perusahaan BUMN di Bursa Efek Indonesia. Jurnal EMBA, Vol. 2, No. 2.

Ranti, Uwuigbe Olubukunola. 2013. Determinants of Dividend Policy: A Study of Selected Listed Firms in Nigeria. Manager Journal, No. 17. 
Ross, Stephen A, Randolph W. Westerfield, and Bradford D. Jordan. 2009. Pengantar Keuangan Perusahaan. Edisi 8. Jakarta: Salemba Empat.

Sadalia, Isfenti dan Nurul Sari Syafitri Saragih. 2008. Pengaruh Profitability dan Investment Opportunity Set Terhadap Dividen Tunai Pada Perusahaan Terbuka di Bursa Efek Indonesia. Jurnal Manajemen Bisnis, Vol. 1, No. 3.

Santoso, Singgih. 2000. Buku Latihan SPSS Statisitik Parametrik. Jakarta: PT. Elex Media Komputindo.

Santoso, Singgih. 2012. Aplikasi SPSS pada Statistik Parametrik. Jakarta: PT. Elex Media Komputindo.

Sekaran, Uma dan Roger Bougie. 2013. Research Methods for Business: A Skill-Building Approach, 6 ${ }^{\text {th }}$ Edition. UK: John Wiley \& Sons Ltd.

Sitanggang, Vista Yuniarti dan Yeni Agustina. 2011. Faktor-Faktor yang Mempengaruhi Pembayaran Dividen pada Perusahaan Manufaktur yang terdaftar di Bursa Efek Indonesia. Jurnal IImiah ESAI, Vol. 5, No.3. , Sumiadji. 2011. Analisis Variabel Keuangan Yang Mempengaruhi Kebijakan Deviden. Jurnal Dinamika Akuntansi, Vol. 3, No.2: 129-138.

Weston, J. Fred, Scott Besley, and Eugene F. Bringham. 1996. Essentials of Managerial Finance. Eleventh Edition. The Dryden Press.

Weygandt, Jerry J., Paul D. Kimmel, and Donald E. Kieso. 2011. Financial Accounting. IFRS Edition. UK: John Wiley \& Sons, Inc. 